\title{
PCSK9 and its clinical importance with the new therapeutic targets against dyslipidemia
}

\author{
A PCSK9 e sua relevância clínica com os novos alvos terapêuticos contra a dislipidemia
}

\author{
Carlos Eduardo dos Santos Ferreira ${ }^{1,2}$, Francisco Antônio Helfenstein Fonseca ${ }^{2}$, Cristóvão Luis Pitangueira Mangueira ${ }^{1}$
}

\begin{abstract}
This is a remarkable progress; since the finding of statins, there was no new way of reducing, significantly, cholesterol and LDL fraction. It is also clear that this decrease, by statins, is related to future cardiovascular lesions, being useful in its primary and secondary prophylaxis. The authors presented studies on research to promote the falling of blood cholesterol by means of antibodies, which inhibit the pro-protein PCSK9, as well as agents that act performing the RNA interference. We had two advantages immediately: for patients with myopathy associated with statins, and the fact of being injected every 15 days, that may contribute to better treatment adherence.
\end{abstract}

Keywords: Dyslipidemias; Lipoproteins; Cholesterol, LDL

\section{RESUMO}

Este é um progresso sensível; desde a descoberta das estatinas, não havia novas maneiras de diminuir, de maneira significativa, 0 colesterol e a fração LDL. Também está claro que essa redução, pelas estatinas, tem relação com futuras lesões cardiovasculares, sendo útil na profilaxia primária e secundária destas. Os autores apresentaram estudos sobre pesquisas para promover a queda do colesterol sanguíneo por meio de anticorpos que inibem a pró-proteína PCSK9, bem como agentes que atuam realizando a interferência no RNA. Duas vantagens se afiguram imediatamente: para pacientes que têm a miopatia relacionada às estatinas e por ser droga injetável a cada 15 dias, o que pode colaborar para maior adesão ao tratamento.

Descritores: Dislipidemias; Lipoproteínas; LDL-colesterol

\section{INTRODUCTION}

The proprotein convertase subtilisin/kexin type 9 , also known as PCSK9, is an enzyme that is encoded by gene PCSK9 ${ }^{(1)}$ in humans, and has orthologous genes found in virtually all species. This gene encodes a proprotein convertase from the proteinase K subfamily, of the secretory subtilase family. The encoded protein is synthesized as a soluble zymogen, which undergoes an intramolecular self-catalytic processing in the endoplasmic reticulum. This protein plays an essential role in regulation of cholesterol homeostasis. PCSK9 binds to the repetition domain $A$, of the epidermal growth factor (EGF-A), to the low-density lipoprotein receptor (R-LDL), inducing degradation of this receptor. These reduced R-LDL levels result in decreased metabolism of low-density lipoproteins (LDL-cholesterol - LDL-c), which could lead to hypercholesterolemia ${ }^{(2,3)}$.

\section{CLINICAL RELEVANCE}

Inhibiting function of PCSK9 is explored as a way to reduce cholesterol levels. Research has advanced in studying antibodies against this enzyme, aiming at its inhibition. It is worth mentioning that the use of statins is well established in clinical practice. Statins interfere in cholesterol production by inhibiting the enzyme HMG-CoA reductase ${ }^{(4)}$ and stimulating the production of LDL receptors; meanwhile, these antibodies allow more LDL receptors to be available ${ }^{(5)}$.

Currently, four different therapeutic targets against PCSK9 are under investigation; in that, Ac anti-PCSK9 - REGN727/SAR236553 (Regeneron Pharmaceuticals/ Sanofi) has more data available ${ }^{(6)}$.

The most recent phase II study was published online on October 31, 2012, in the New England Journal of Medicine, and was carried out by a tem led by Dr. Eli Roth. The project involved 92 patients, with

\footnotetext{
Hospital Israelita Albert Einstein - HIAE, São Paulo (SP), Brazil.

${ }^{2}$ Universidade Federal de São Paulo - UNIFESP, São Paulo (SP), Brazil.
}

Corresponding author: Carlos Eduardo dos Santos Ferreira - Avenida Albert Einstein, 627/701 - $4^{\text {th }}$ floor - Building D - Clinical Laboratory - Morumbi - Zip code: $06551-901$ - São Paulo (SP), Brazil Phone: (55 11) 2151-2430 - E-mail: carlosesf@einstein.br

Received on: Apr 6, 2012 - Accepted on: Dec 12, 2012

Conflict of interest: none. 
LDL levels $\geq 100 \mathrm{mg} / \mathrm{dL}$ after receiving atorvastatin $10 \mathrm{mg}$ for at least 7 weeks. They were randomized for 8-week treatment, at the ratio of 1:1:1 - receiving atorvastatin 80mg/day + REGN727/SAR236553; atorvastatin $10 \mathrm{mg} /$ day + REGN727/SAR236553 and atorvastatin $80 \mathrm{mg} /$ day + placebo. The drug REGN727/ SAR236553 was administered every two weeks, subcutaneously. The exclusion criteria included type-1 diabetes mellitus, uncontrolled type- 2 diabetes mellitus (glycated hemoglobin $>8.5 \%$ ) or on insulin, triglycerides $>350 \mathrm{mg} / \mathrm{dL}$ or any cardiovascular events in the past 6 months before the study. The results on the monoclonal antibody anti-PCSK9 REGN727/SAR236553 showed important reduction in LDL levels, in both associations (atorvastatin $10 \mathrm{mg}$ and $80 \mathrm{mg}$ ) in patients with primary dyslipidemia (Table 1). In the placebo group, the drop was by $2.7 \%$ only. Like in previous studies with the same therapy, there was a decrease by approximately one-third lipoprotein-a Lp (a) levels in patients who received the antibody ${ }^{(7)}$.

The Odyssey study with this antibody is on its phase III since July 2012. A total of 22000 patients will be enrolled, distributed throughout 2000 centers all over the world (United States, Europe, Canada, Australia, Asia and South America, including Brazil). It is conducted by Professor Dr Henry Ginsberg, of the Columbia University Medical Center, in New York.

Another way to inhibit the action of PCSK9 would be to use the therapeutic targets that act interfering in RNA, that is, RNA interference (RNAi) ${ }^{(8)}$. The RNAi is a great advance in medicine, and represents understanding of how genes are switched on and off in the cells, and provides a totally new approach to discovery and development of new medications. Its discovery was announced as "a great scientific advance

Table 1. Reductions in LDL-cholesterol in patients with primary dyslipidemia

\begin{tabular}{lcc}
\hline Groups & $\begin{array}{c}\text { Reduction in LDL } \\
\text { levels from baseline } \\
(\%)\end{array}$ & $\begin{array}{c}\text { p value } \\
\text { (versus atorvastatin } \\
\text { 80 mg + placebo) }\end{array}$ \\
\hline Atorvastatin 80mg + antibody & 73.2 & $<0.001$ \\
Atorvastatin 10mg + antibody & 66.2 & $<0.001$ \\
Atorvastatin 80mg + placebo & 17.3 & - \\
\hline
\end{tabular}

that occurs once in every ten or more years" and it represents one of the most promising findings, being awarded the Nobel Prize of Physiology, in 2006 ${ }^{(9,10)}$. Alnylam Pharmaceuticals recently demonstrated in initial clinical trials (Phase 1), the positive results of the new drug ALN-PCS, which has the same action, and effectively inhibits this proprotein.

New studies will be published soon, enabling a better evaluation of these promising therapeutic targets.

\section{REFERENCES}

1. Seidah NG, Benjannet S, Wickham L, Marcinkiewicz J, Jasmin SB, Stifani $S$, et al. The secretory proprotein convertase neural apoptosis-regulated convertase 1 (NARC-1): liver regeneration and neuronal differentiation. Proc Natl Acad Sci. 2003;100(3):928-33.

2. Dubuc G, Chamberland A, Wassef H, Davignon J, Seidah NG, Bernier $L$, et al. Statins upregulate PCSK9, the gene encoding the proprotein convertase neural apoptosis-regulated convertase-1 implicated in familial hypercholesterolemia. Arterioscler Thromb Vasc Biol. 2004;24(8):1454-9.

3. Horton JD, Cohen JC, Hobbs HH. Molecular Biology of PCSK9: its role in LDL metabolism. Trends Biochem Science. 2006,32(2):71-7.

4. Sposito AC, Caramelli B, Fonseca FA, Bertolami MC, Afiune Neto A, Souza $A D$, Lottenberg AM, Chacra AP, Faludi AA, Loures-Vale AA, Carvalho AC, Duncan B, Gelonese B, Polanczyk C, Rodrigues Sobrinho CR, Scherr C, Karla C, Armaganijan D, Moriguchi E, Saraiva F, Pichetti G, Xavier HT, Chaves H, Borges JL, Diament J, Guimarães JI, Nicolau JC, dos Santos JE, de Lima JJ, Vieira JL, Novazzi JP, Faria Neto JR, Torres KP, Pinto Lde A, Bricarello L, Bodanese LC, Introcaso L, Malachias MV, Izar MC, Magalhães ME, Schmidt MI, Scartezini M, Nobre M, Foppa M, Forti NA, Berwanger 0, Gebara OC Coelho OR, Maranhão RC, dos Santos Filho RD, Costa RP, Barreto S, Kaiser S, Ihara S, Carvalho T, Martinez TL, Relvas WG, Salgado W; Sociedade Brasileira de Cardiologia. [IV Brazilian Guideline for Dyslipidemia and Atherosclerosis prevention: Department of Atherosclerosis of Brazilian Society of Cardiology]. Arq Bras Cardiol 2007;88 Suppl 1:2-19. Article in Portuguese.

5. Lopez D. Inhibition of PCSK9 as a novel strategy for the treatment of hypercholesterolemia. Drug News Perspect. 2008;21(6):323-30.

6. Steinberg D and Witztum JL. Inhibition of PCSK9: A powerful weapon for achieving ideal LDL cholesterol levels. Proc Natl Acad Sci. 2009;106(24):9546-7.

7. Roth EM, McKenney JM, Hanotin C, Asset G, Stein EA. Atorvastatin with or without Antibody to PCSK9 in Primary Hipercholestorelemia. New Eng J Med. 2012 Oct 31. Epub ahead of print.

8. Wu CY, Tang ZH, Jiang L, Li XF, Jiang ZS, Liu LS. PCSK9 siRNA inhibits HUVEC apoptosis induced by ox-LDL via Bcl/Bax-caspase9-caspase3 pathway. Mol Cell Biochem. 2012;359(1-2):347-58

9. Fire A, Xu S, Montgomery M, Kostas S, Driver S, Mello C. Potent and specific genetic interference by double-stranded RNA in Caenorhabditis elegans. Nature. 1998;391(6669):806-11.

10. Bertil D. Advanced Information: RNA interference. The Nobel Prize in Physiology or Medicine 2006 [Internet]. [cited 2012 0ct 14]. Available from: http://www. nobelprize.org/nobel_prizes/medicine/laureates/2006/advanced.htm 